\title{
Studi Fenomenologi tentang Faktor Risiko Penularan \\ Tuberculosis Paru di Perumnas Way Kandis Lampung
}

\author{
Fitria Saftarina1, Amelia Dwi Fitri² \\ ${ }^{1}$ Bagian Kedokteran Komunitas-IImu Kesehatan Masyarakat, Fakultas Kedokteran, \\ Universitas Lampung \\ ${ }^{2}$ Bagian Pendidikan Kedokteran, Fakultas Kedokteran dan Kesehatan, Universitas Jambi \\ Email: fitria.saftarinadr@gmail.com
}

\begin{abstract}
Pulmonary tuberculosis (TB) is a contagious disease caused by Mycobacterium tuberculosis with the highest mortality rate in worldwide. Indonesia is one of big five country with the highest incidency. Based on distribution per province, Lampung was in the tenth with 7,627 new TB cases in 2017. The purpose of this research was to determine the risk factors of pulmonary tuberculosis in Perumnas Way Kandis Subdistrict. Methods:This is a qualitative research with phenomenological approach. Samples was determined purposively based on appropriateness and adequateness. This research involved 5 people with BTA (+) who are undergoing treatment and 5 people who are the patients' close family as informant. Data was collected by observation and interview. Data validity was maintained with triangulation and analysed with Milles and Huberman Model.

Results: Based on indepth interview, understanding of the informants of TB was good; most of informants did not know the ways and the sources of TB transmission; informants had a habit of not using masks; most of informants with TB do a routine treatment; the close family of informants with TB support and remind them taking medication; distance of the houses between informants with TB is close enough, do not have good sun lighting and air circullation. Conclusion: The priority cause of TB is the low compliance in using masks so the priority solution is to distribute masks for TB patients.
\end{abstract}

\section{Keywords: Indepth interview, mask, tuberculosis}

\begin{abstract}
Abstrak
Tuberkulosis (TB) merupakan penyakit menular yang disebabkan oleh Mycobacterium tuberculosis dengan angka kematian tertinggi di dunia. Indonesia termasuk dalam lima besar negara dengan insiden tertinggi. Berdasarkan sebaran per provinsi, Lampung berada di posisi kesepuluh dengan 7.627 kasus TB baru pada tahun 2017. Penelitian ini bertujuan untuk mengetahui faktor risiko penularan TB paru di Kelurahan Perumnas Way Kandis. Penelitian ini merupakan penelitian kualitatif dengan pendekatan fenomenologi. Pemilihan sampel ditetapkan secara langsung (purposive) dengan prinsip kesesuaian (appropriateness) dan kecukupan (adequateness). Jumlah sampel terdiri dari 5 orang pasien BTA (+) yang sedang menjalani pengobatan dan 5 orang keluarga terdekat pasien sebagai informan. Pengumpulan data dilakukan dengan observasi dan wawancara. Validitas data dijaga dengan triangulasi dan analisis data menggunakan model Milles dan Huberman.

Hasil: Berdasarkan indepth interview, pengetahuan informan mengenai TB sudah baik; sebagian informan tidak mengetahui cara dan sumber penularan TB; informan memiliki kebiasaan tidak menggunakan masker; sebagian besar informan dengan penyakit TB melakukan pengobatan secara rutin; keluarga besar informan
\end{abstract}


dengan penyakit TB mendukung dan mengingatkan untuk minum obat; jarak rumah antarpenderita TB berdekatan serta tidak memiliki pencahayaan matahari dan sirkulasi udara yang baik.

Kesimpulan: Prioritas penyebab TB adalah rendahnya kepatuhan menggunakan masker sehingga jalan keluar yang diprioritaskan adalah dengan kegiatan pembagian masker bagi para penderita TB.

Kata kunci: Indepth interview, masker, tuberkulosis

\section{Pendahuluan}

Tuberkulosis (TB) Paru merupakan penyakit infeksi bakteri menular dengan angka kematian tertinggi di dunia. Pada tahun 2016, WHO melaporkan bahwa terdapat sekitar 10,4 juta kasus infeksi TB dan 1,8 juta kasus kematian akibat TB. Angka kejadian penyakit ini meningkat pada negara-negara berpenghasilan rendah. ${ }^{1}$ Lima negara dengan insiden kasus tertinggi yaitu India, Indonesia, Filipina, dan Pakistan. Berdasarkan data per 17 Mei 2018, jumlah kasus baru TB di Indonesia sebanyak 420.994 kasus pada tahun 2017. Berdasarkan sebaran per provinsi, sepuluh besar provinsi dengan jumlah kasus TB tertinggi se-Indonesia adalah Jawa Barat, Jawa Timur, Jawa Tengah, DKI Jakarta, Sumatera Utara, Banten, Sumatera Selatan, Sulawesi Selatan, Sumatera Barat dan Lampung. Jumlah kasus TB di Lampung pada tahun 2017 sebanyak 7.627 kasus. $^{3}$

Tuberkulosis disebabkan oleh Mycobacterium tuberculosis yang ditandai dengan pembentukan granuloma padajaringan yang terinfeksi. Tuberkulosis menginfeksi paru-paru, tetapi dapat menyebar kehampir seluruh bagian tubuh seperti meninges, ginjal, tulang, dan nodus limfe. Tuberkulosis menular dari penderita melalui udara. Ketika penderita TB paru batuk, bersin atau meludah, mereka mengeluarkan kuman TB ke udara yang dapat di hirup oleh orang yang sehat. Cara transmisi yang sederhana seperti ini menyebabkan angka kejadian TB mudah meningkat.Penyakit TB yang disebabkan terjadi ketika daya tahan tubuh menurun. Pengidap HIV AIDS atau orang dengan status gizi buruk lebih mudah terinfeksi dan terjangkit TB. ${ }^{2}$

Apabila dilihat dari angka keberhasilan (succes rate), yaitu jumlah keseluruhan kasus TB sembuh dan pengobatan lengkap di antara semua kasus TB yang diobati dan yang dilaporkan, WHO menetapkan standar keberhasilan pengobatan sebesar $85 \% .^{3}$ Pada tahun 2017, Indonesia mencapai target angka keberhasilan, yaitu $85,1 \%{ }^{2}$ Demikian pula dengan Case Notification Rate (CNR) dan Treatment Success Rate (TSR) di Provinsi Lampung sudah mencapai strategi nasional, yaitu CNR 99/100.000 penduduk dan TSR lebih dari 90\%, terutama di Kabupaten Pesawaran, Tanggamus, dan Way Kanan di tahun 2016.4

Provinsi Lampung memiliki luas wilayah sebesar $34.623,80 \mathrm{~km}^{2}$ dengan jumlah penduduk sebanyak 8.117.268 jiwa. 5,6 Pada tahun 2006 angka kejadian TB tercatat sebesar 501 kasus per 100.000 penduduk, sedangkan pada tahun 2007 
angka kejadian TB tercatat sebesar 549 kasus per 100.000 penduduk dimana angka kejadian terbanyak berada di wilayah kota Bandar lampung. ${ }^{7}$ Berdasarkan data yang diperoleh dari kader P2M TB paru di Puskesmas Rawat Inap Way Kandis, didapatkan kelurahan yang memiliki angka terbanyak kejadian TB Paru berada di Kelurahan Perumnas Way Kandis sebanyak 13 kasus. ${ }^{8}$ Berdasarkan latar belakang ini, penulis tertarik untuk melakukan analisis kualitatif mengenai faktor risiko penularan penyakit TB Paru di Kelurahan Perumnas Way Kandis Kecamatan Tanjung Senang.

\section{Metode}

Penelitian ini merupakan penelitian kualitatif dengan pendekatan fenomenologi. ${ }^{9}$ Penggunaan pendekatan ini bertujuan untuk memperoleh data yang menggambarkan faktor risiko apa saja yang dapat menyebabkan penularan penyakit TB paru di Kelurahan Perumnas Way Kandis, Kecamatan Way Kandis.

Penelitian ini dilaksanakan pada bulan Juli 2018 di kelurahan Perumnas Way Kandis, Kecamatan Tanjung Senang. Pemilihan lokasi didasarkan hasil laporan dari Puskesmas Way Kandis, bahwa angka prevalensi di kelurahan Perumnas Way Kandis tertinggi untuk di wilayah Kerja Puskesmas Way kandis Kecamatan Tanjung Senang.
Tabel 1 . Penyebaran Kejadian TB Paru 2018

\begin{tabular}{clc}
\hline No & \multicolumn{1}{c}{ Kelurahan } & Kejadian TB \\
\hline 1 & Tanjung Senang & 7 \\
2 & Way Kandis & 8 \\
3 & Perumnas Way Kandis & 13 \\
4 & Labuhan Dalam & 8 \\
5 & Pematang Wangi & 3 \\
& Jumlah & 45 \\
\hline
\end{tabular}

Pemilihan sampel ditetapkan secara dengan teknik purposive sampling dengan prinsip kesesuaian (appropriateness) dan kecukupan (adequateness) yang disesuaikan dengan kriteria berikut ini. ${ }^{10}$

1. Penduduk di Kelurahan Perumnas Way Kandis, berusia 20-45 tahun, termasuk 5 orang pasien BTA (+) yang sedang menjalani pengobatan dan 5 orang yang merupakan keluarga terdekat pasien;

2. Bersedia diwawancara secara mendalam.

Secara garis besar, sumber data dibagi menjadi dua kelompok, yaitu data primer yang diperoleh melalui observasi dan wawancara mendalam dan data sekunder yang diperoleh dari arsip-arsip resmi. Instrumen penelitian adalah peneliti itu sendiri dengan menggunakan pedoman wawancara. Data yang telah dikumpulkan divalidasi dan dijaga validitasnya dengan triangulasi, yaitu pendekatan multimetode sehingga dapat diperoleh kebenaran tingkat tinggi. Pada penelitian ini digunakan triangulasi sumber dengan melihat masalah dari sudut pandang informan yang berbeda. Identifikasi masalah diawali dengan observasi lingkungan, selanjutnya dilakukan wawancara mendalam kepada informan, koding data, triangulasi, dan selanjutnya 
data dianalisis dengan model Miles \& Huberman. ${ }^{11}$ Prioritas faktor risiko ditentukan dengan metode USG (urgency, seriousness and growth). Penyebab masalah ditentukan dengan membandingkan standar komponenkomponen input, proses, output, lingkungan, dan umpan balik. Setelah itu, dibuat alternatif pemecahan masalah dengan metode matriks.

\section{Hasil}

Kelurahan Perumnas Way Kandis terletak di Kecamatan Way Kandis dengan luas Wilayah kerja \pm 973 Ha. Karakteristik informan pada penelitian adalah sebagai berikut:

Tabel 2. Karakteristik Informan

\begin{tabular}{|c|c|c|}
\hline No & Variabel & Jumlah \\
\hline \multirow[t]{5}{*}{1} & Umur & \\
\hline & a. 20-25 tahun & 2 orang \\
\hline & b. $26-30$ tahun & 4 orang \\
\hline & c. $30-35$ tahun & 2 orang \\
\hline & d. 40-45 tahun & 2 orang \\
\hline \multirow[t]{3}{*}{2} & Jenis Kelamin & \\
\hline & a. Laki laki & 5 orang \\
\hline & b. Perempuan & 5 orang \\
\hline \multirow[t]{3}{*}{3} & Pendidikan terakhir & \\
\hline & a. SMP & 6 orang \\
\hline & b. SMA & 4 orang \\
\hline
\end{tabular}

Berdasarkan indepth interview didapatkan 7 kategori sebagai berikut:

Tema 1: Pengetahuan informan mengenai penyakit dan gejala dari TB paru sudah baik. Hal tersebut sesuai dengan pernyataan informan sebagai berikut.
"Tuberkulosis itu TBC ya mba, batuk berdarah......." (X1)

"TB itu tuberkulosis mba...." (X2)

"batuk lama mba, yang berdahak ada darahnya...." (X3)

"itu batuk berdarah..." (X4)

"paru paru basah bukan si mbak?" (X5)

"TB itu saat orang sakit batuk lama, batuk berdarah, berdahak juga.Setahu saya kuman nya menular mba..." (X6) "Kalau yang saya tahu sih TB itu penyakit keturunan. Orang yang sakit TB pasti batuk, kadang ada darahnya, badannya bisa kurus banget. Biasanya pengobatan lama dan gak boleh putus. Biasanya minum obat merah." (X7)

"sakit batuk lama, menular...." (X8)

" batuk lebih dari dua minggu, berdahak, kadang ada darah......" (X9) "paru-parunya ada fleknya" (X10)

Tema 2: Sumber penularan TB Paru.

Beberapa informan tidak mengetahui bahwa penularan TB terjadi melalui droplet yang dapat tersebar melalui udara, sebagaimana yang dikemukakan informan sebagai berikut.

"Ya saya sih taunya penularannya lewat kuman yang ada berada pada bekas tempat makan orang TB." (X1)

"dari batuk kan ya mbak menularnya" (X2)

"dari ludah orang yang sakit TB itu" (X3)

"kayaknya dari minuman atau makanan bekas orang TB." (X4) 


"apa ya mbak?" (X5)
"kayakanya kalo... gatau mbak
kayaknya kalau deket deket bisa nular."
(X6)
"keturunan itu mbak, itu deket rumah
saya bapak sama anaknya juga tuh
mbak." (X7)
"dari batuknya mba, kalo saya ga pake
masker bisa nularin" (X8)
"agaknya dari dahaknya mba" (X9)
"dari batuk orang yang sakit TB mba"
(X10)

Tema 3: Kebiasaan menggunakan alat pelindung diri (APD).

Informan tidak menggunakan masker saat beraktivitas di luar maupun di dalam rumah sebagaimana dikemukakan informan sebagai berikut.

"ya kalo saya sih gak pernah pakek
masker kalok dirumah, tapi kalok
keluar pakek tapi itu juga jarang.
Soalnya susah napas." (x2)
"kalok saya sama gak suka pakek
masker, karena saya ngerasa
pengap." (x3)
"kalok saya pakek sih, kalok ada tamu
aja, tapi kalok keluar rumah kadang
pakek kadang enggak, soalnya gak
punya duit buat beli maskerterus." (x8)
"saya pakai masker kalau ambil obat
aja mbak biar gak dimarahin." (x9)
"males belinya mbak, mahal" (x10)

Tema 4: Cara membuang dahak.

Informan juga membagikan informasi mengenai cara membuang dahaknya sebagaimana disampaikan oleh informan berikut.

"Ya saya kalok buang dahak ditissue, terus saya buang ke kotak sampah, kalok buang sembarangan nanti bisa nularin keorang lain." (x2)

“kalok saya punya pot kusus dari aqua bekas yang dikasih pasir aja gak saya kasih lisol yang katanya buat bunuh kuman. Saya gak tau lisol itu apa." (x3) "kalok saya buang dahak di kamar mandi, terus saya siram pakek air." $(x 8)$

"ya buang dahak biasa mbak, diludahin gitu aja di luar rumah." (x9) "saya buang pakai tissue kadang mbak, kadang dikamar mandi aja" $(x 10)$

Tema 5: Keteraraturan pengobatan TB Paru.

Berdasarkan hasil indepth interview didapatkan bahwa 4 informan menyatakan rutin melakukan pengobatan penyakit TB paru. Meskipun terdapat 1 informan yang tidak melakukan pengobatan rutin, sesuai dengan yang dikatakan dengan informan sebagai berikut.

"Alhamdulillah, kalok saya berobat terus, soalnya saya mau sembuh. Kalok sembuh kan gak bisa nularin keorang lain." (x2)

"saya ambil obat terus sebulanan ini di puskes itu mbak." (x3)

"rutin dong mbak, udah 4 bulan ini." (x8) 


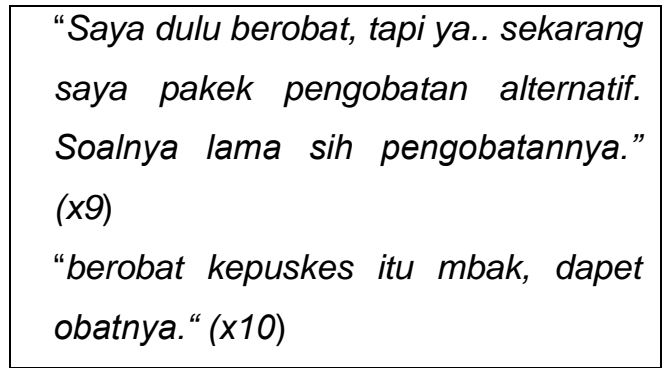

Tema 6: Dukungan keluarga dalam melakukan pengawasan minum obat.

Sebanyak 4 informan menyatakan bahwa keluarga informan mendukung dan selalu mengingatkan untuk minum obat. Sesuai dengan yang dikatakan dengan informan berikut.

\footnotetext{
"saya minum obat selalu tepat waktu soalnya diingetin sama keluarga untuk minum obat." $(x 2)$

"iya diingetin mbak buat minum obat, malah dimarahin kalau gak kepuskes ambil obat" ( $\times 3)$

"istri saya itu mbak pasti langsung nyodorin obat itu mbak sambil diliatin malah." (x8)

"wah iya mbak, makanya kita juga dateng ke alternatif alternatif itu" ( $x 9$ ) "iya alhamdulillah diminum terus obatnya mbak gak putus putus kok" (x10)
}

Tema 7: Kondisi rumah dan lingkungan.

Sebanyak 5 informan mengatakan bahwa letak rumah dengan pasien TB lainnya berdekatan dan rata-rata kondisi rumah setiap penderita memiliki kondisi rumah dengan pencahayaan dan sirkulasi yang tidak baik. Sesuai dengan kalimat yang diutarakan informan sebagai berikut. "ya tetangga saya banyak yang TB dan rumah kami berdektan. Jendela rumah saya sering saya buka, tapi sinar matahari tetap gak masuk. Ketutupan rumah tetangga." (x2) "saya jarang buka buka jendela, karena banyak debu masuk karena kereta yang sering lewat depan rumah saya." (x3)

"ya kayak yang mba lihat, rumah nya rapet-rapet. Kemarin rumah sebelah juga batuk lama kayak saya" (x8) "depan rumah saya banyak debu mba, saya ingin sih pindah. Tapi gak punya uang mba" (x9)

"iya mba, sinar matahari emang ketutupan, jadi kerasa lembab rumahnya" (x10)

Hasil observasi dan indepth interview terhadap informan dianalisis dengan Model Miles \& Huberman dapat ditarik beberapa masalah utama terkait faktor-faktor penyebab penularan TB paru adalah sebagai berikut :

1. Kurangnya pengetahuan masyarakat kelurahan Perumnas Way Kandis tentang faktor penularan penyakit TB.

2. Adanya kebiasaan tidak menggunakan alat pelindung diri (masker) pada penderita TB.

3. Kondisi ekonomi keluarga yang masih rendah untuk menciptakan rumah dan lingkungan yang sehat.

4. Lokasi rumah penduduk yang sangat padat dan berdekatan antar rumah Hal ini dapat dilihat pada diagram fishbone (Gambar 1). 


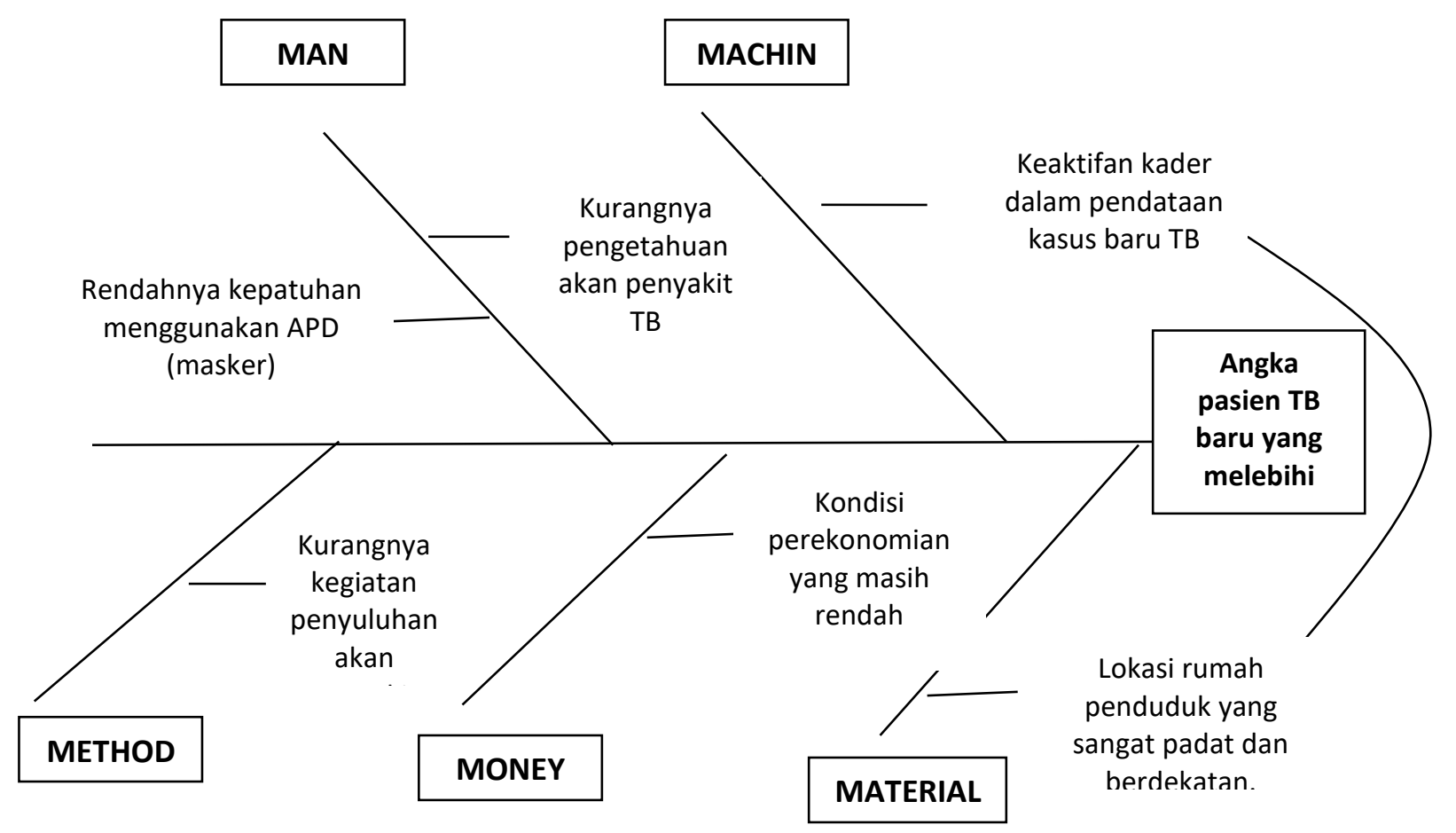

Gambar 1. Diagram fishbone 
Berdasarkan wawancara dengan pihak pemegang program Penyakit Menular (P2M) di Puskemas Way Kandis, didapat informasi sebagai berikut:

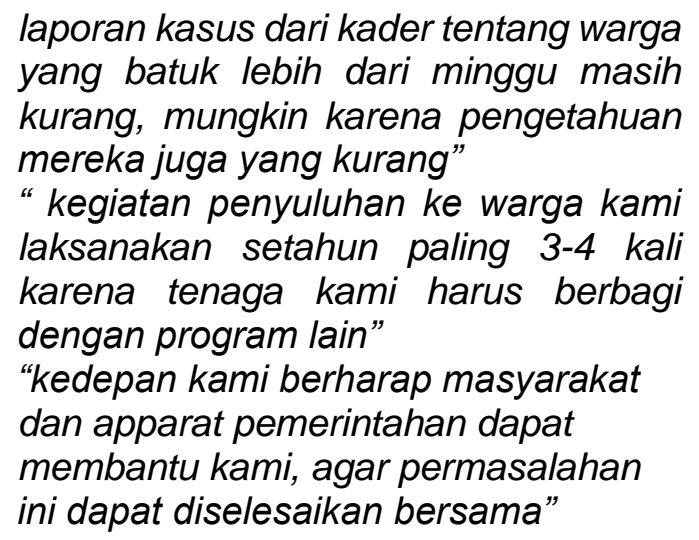

Masalah kesehatan utama di kelurahan Perumnas Way Kandis berupa masih banyak faktor-faktor penyebab penularan penyakit TB:
1. Rendahnya pengetahuan masyarakat kecamatan Perumnas Way Kandis tentang penyakit TB.

2. Rendahnya kepatuhan masyarakat kecamatan Perumnas Way Kandis akan penggunaan APD (masker).

3. Kondisi ekonomi keluarga yang masih rendah.

4. Lokasi rumah penduduk yang sangat padat dan berdekatan.

5. Kurangnya keaktifan kader dalam pendataan kasus baru TB.

6. Kurangnya kegiatan penyuluhan akan penyakit TB.

Menilai dan meninjau kapasitas dari kelurahan Perumnas Way Kandis perlu dilakukan pengukuran prioritas masalah. Metode yang digunakan untuk menentukan prioritas masalah kesehatan dalam hal ini peneliti memilih USG (Urgency, Seriousness Growth), yang dilihat pada Tabel 5 .

Tabel 5. Tabel Prioritas Masalah USG

\begin{tabular}{|c|c|c|c|c|}
\hline Masalah & Urgency & Seriousness & Growth & Total \\
\hline $\begin{array}{l}\text { Rendahnya pengetahuan masyarakat kelurahan } \\
\text { Perumnas Way Kandis tentang penyakit TB. } \\
\text { Rendahnya kepatuhan masyarakat kelurahan }\end{array}$ & 3 & 3 & 2 & 8 \\
\hline $\begin{array}{l}\text { Perumnas Way Kandis akan penggunaan APD } \\
\text { (masker). }\end{array}$ & 4 & 5 & 4 & 13 \\
\hline Kondisi ekonomi keluarga yang masih rendah. & 3 & 2 & 2 & 7 \\
\hline $\begin{array}{l}\text { Lokasi rumah penduduk yang sangat padat dan } \\
\text { berdekatan. }\end{array}$ & 2 & 2 & 1 & 5 \\
\hline $\begin{array}{l}\text { Kurangnya keaktifan kader dalam pendataan kasus } \\
\text { baru TB. }\end{array}$ & 3 & 3 & 3 & 9 \\
\hline Kurangnya kegiatan penyuluhan akan penyakit TB. & 2 & 2 & 1 & 5 \\
\hline
\end{tabular}

Berdasarkan prioritas masalah menggunakan metode Urgensi Seriuousnes Growth (USG) didapatkan rendahnya kepatuhan masyarakat kelurahan Perumnas
Way Kandis akan penggunaan APD (masker). Selanjutnya prioritas pemecahan masalah dengan metode matriks dapat dlihat pada Tabel 6 . 
Tabel 6. Prioritas Pemecahan Masalah

\begin{tabular}{|c|c|c|c|c|c|}
\hline \multirow{2}{*}{ Pemecahan Masalah } & \multicolumn{3}{|c|}{ Efektivitas } & \multirow{2}{*}{$\begin{array}{c}\text { Efisien } \\
\text { si } \\
\text { C }\end{array}$} & \multirow[t]{2}{*}{ Jumlah MIV/C } \\
\hline & $\mathbf{M}$ & I & V & & \\
\hline Sosialisasi mengenai dampak penularan & & & & & \\
\hline penyakit TB, akibat tidak menggunakan & 2 & 2 & 3 & 1 & 12 \\
\hline APD. & & & & & \\
\hline $\begin{array}{l}\text { Melakukan penyuluhan tentang rumah } \\
\text { sehat. }\end{array}$ & 3 & 3 & 2 & 1 & 18 \\
\hline $\begin{array}{l}\text { Kegiatan pembagian masker kepada } \\
\text { penderita TB. }\end{array}$ & 4 & 4 & 3 & 2 & 24 \\
\hline
\end{tabular}

$\begin{aligned} & \text { Dari } \text { cara pemecahan terpilih } \\ & \text { didapatkan perlu dilakukan kegiatan }\end{aligned}$ pembagian masker kepada penderita TB. Hal ini perlu dilakukan untuk mencegah penularan dari penderita. Pemakaian masker terutama diwajibkan pada penderita TB fase intensif.

\section{Pembahasan}

Hasil penelitian menunjukkan bahwa pengetahuan informan mengenai penyakit dan gejala TB paru sudah baik. Namun, beberapa informan tidak mengetahui faktor penularan penyakit TB. Para informan mengatakan bahwa TB menular melalui peralatan makanan bahkan ada yang mengatakan bahwa TB merupakan penyakit keturunan. Informan menganggap bahwa ini adalah penjelasan untuk beberapa penderita TB yang memiliki hubungan keluarga dan tinggal serumah. Sementara, pada dasarnya TB paru menular melalui droplet penderita yang dapat tersebar melalui udara. Sebagaimana disimpulkan dalam penelitian Rusnoto, fenomena ini dapat terjadi karena penularan penyakit TB berhubungan dengan riwayat kontak dengan anggota keluarga. ${ }^{12}$

Pengetahuan seseorang mengenai TB paru dipengaruhi oleh beberapa faktor seperti tingkat pendidikan, pengalaman, dan fasilitas. Ketiga faktor ini berhubungan dengan sumber informasi yang diterima oleh masyarakat mengenai TB paru. Individu dengan tingkat pendidikan yang lebih tinggi cenderung lebih dekat dengan sumber informasi, baik dari orang-orang di sekitarnya maupun media massa. Sementara orang yang berpengalaman belajar dari pengalamannya sendiri. ${ }^{13}$ Selain itu, fasilitas kesehatan juga berperan dalam menambah wawasan masyarakat mengenai penyakit ini. Kurangnya penyuluhan kesehatan mengenai penyakit ini sebanding dengan kurangnya pengetahuan masyarakat mengenai TB paru. ${ }^{14}$

Rendahnya pengetahuan masyarakat mengenai penyakit TB paru menyebabkan rendahnya kesadaran masyarakat mengenai bahaya penyakit ini sehingga upaya-upaya pencegahan penularan penyakit ini tidak terlalu diperhatikan. Salah satu upaya pencegahan penularan TB yang dapat diupayakan oleh masing-masing 
penderita adalah dengan menggunakan alat pelindung diri (APD) berupa masker. ${ }^{15}$ Sejalan dengan penelitian pada tahun 2018 yang menyatakan bahwa proteksi penularan TB dapat dilakukan dengan meminum obat anti-tuberkulosis (OAT) sesuai dengan anjuran dokter, menggunakan masker di dalam rumah, menutup mulut ketika batuk atau bersin, membuang dahak di WC, menggunakan alat makan dan minum terpisah dengan anggota keluarga lainnya, dan menjemur peralatan tidur yang digunakan. ${ }^{16}$ Warga Kelurahan Perumnas Way Kandis yang menjadi informan penelitian ini memiliki kebiasaan tidak menggunakan masker. Mereka mengaku tidak menggunakannya karena mereka tidak nyaman menggunakan masker dan juga karena harganya yang mahal.

Selain itu, kondisi ekonomi keluarga yang masih rendah berdampak pada upaya menciptakan rumah dan lingkungan rumah yang sehat. Penelitian di Kabupaten Kendal pada tahun 2015 menyatakan bahwa kondisi fisik rumah secara statistik berhubungan dengan kejadian TB paru dengan nilai $p<0,05$ secara berturut-turut: suhu ruangan $(p=0,001)$, kelembapan ruangan $(p=0,018)$, jenis lantai rumah $(p=0,016)$, dan intensitas pencahayaan alami $(p=0,006)$. Rumah dengan kondisi tidak sehat atau tidak memenuhi syarat kesehatan dapat sebagai media penularan peyakit paru, salah satunya adalah penyakit TB. Penyakit TB juga diperburuk oleh sanitasi perumahan yang buruk. ${ }^{17}$

Kondisi rumah di Kelurahan Perumnas Way Kandis, selain tidak sehat juga merupakan lokasi rumah penduduk yang sangat padat dan berdekatan antar rumah. Semakin padat rumah, perpindahan penyakit menular ini akan semakin mudah dan cepat. Ventilasi udara dan pencahayaan yang buruk akibat padatnya hunian mengakibatkan rendahnya pertukaran udara sementara droplet yang keluar ketika penderita TB batuk atau bersin dapat bertahan di suhu ruangan selama lebih kurang 2 jam. ${ }^{18} \mathrm{Hal}$ ini menunjukkan bahwa kepadatan hunian merupakan salah satu faktor risiko yang meningkatkan kejadian penyakit TB. ${ }^{17}$

Berdasarkan metode USG, penyebab utama prioritas adalah kebiasaan masyarakat yang tidak menggunakan masker. Dengan demikian, disarankan setiap penderita setidaknya menggunakan satu buah masker dalam satu hari. Sehingga diperlukan pemberian satu kotak masker berisi 100 buah untuk satu penderita TB yang masih aktif menularkan bakteri.

\section{Simpulan}

Prioritas penyebab TB adalah rendahnya kepatuhan masyarakat dalam penggunaan APD (masker) di Kelurahan Perumnas Way Kandis.

\section{Saran}

Pemecahan masalah yang diprioritaskan adalah pembagian masker kepada para penderita TB di Kelurahan Perumnas Way Kandis. 


\section{DAFTAR PUSTAKA}

1. WHO. Global Tuberculosis report 2016. Jenewa: World Health Organization; 2017.

2. Kemenkes RI. Pusat data dan informasi: Tuberkulosis. Jakarta Selatan: Kementerian Kesehatan RI; 2018.

3. Kemenkes RI. Data dan informasi: Profil kesehatan Indonesia 2017. Jakarta Selatan: Kementerian Kesehatan Rl; 2018.

4. Kemenkes RI. Pusat data dan informasi: Tuberkulosis. Jakarta Selatan: Kementerian Kesehatan RI; 2016.

5. BPS Provinsi Lampung. Luas wilayah, jumlah kecamatan dan desa/kelurahan Provinsi Lampung menurut kabupaten/kota, 2013 dan 2015 [internet]. Bandar Lampung: Badan Pusat Statistik Provinsi Lampung; 2017 [disitasi tanggal 31 Januari 2019]. Tersedia dari: https://lampung.bps.go.id/dynamictable/2017/03/27/105/luas-wilayah-jumlah-kecamatan-dan-desakelurahan-provinsi-lampung-menurut-kabupaten-kota-2013-dan-2015.html

6. BPS Provinsi Lampung. Jumlah penduduk dan laju pertumbuhan penduduk menurut kabupaten/kota di Provinsi Lampung, 2020, 2014, 2015 [internet]. Bandar Lampung: Badan Pusat Statistik Provinsi Lampung; 2016 [disitasi tanggal 31 Januari 2019]. Tersedia dari: https://lampung.bps.go.id/statictable/2016/07/29/471/jumlah-penduduk-dan-laju pertumbuhanpenduduk-menurut-kabupaten-kota-di-provinsi-lampung-2010-2014-dan-2015.html

7. Dinkes Provinsi Lampung. Profil kesehatan Provinsi Lampung tahun 2017. Bandar Lampung: Dinas Kesehatan Provinsi Lampung; 2017.

8. Puskesmas Way Kandis. Data Puskesmas Way Kandis 2018. Bandar Lampung: Puskesmas Way Kandis; 2018.

9. Hajaroh M. Paradigma, pendekatan dan metode penelitian fenomenologi. Jurnal Pendidikan UNY [internet]. 2010 [diakses tanggal 22 Agustus 2018]; 1-21. Tersedia dari: http://staffnew.uny.ac.id/upload/132011629/penelitian/fenomenologi.pdf

10. Dahlan MS. Besar sampel dan cara pengambilan sampel dalam penelitian kedokteran dan kesehatan. Jakarta: Salemba Medika; 2013.

11. Afrizal. Metode penelitian kualitatif: Sebuah upaya mendukung penggunaan metode kualitatif dalam berbagai disiplin ilmu. Jakarta: Raja Frafindo Persada; 2015.

12. Rusnoto. Faktor-faktor yang berhubungan dengan kejadian TB paru pada usia dewasa (Studi kasus di Balai Pencegahan dan pengobatan penyakit paru pati) [tesis]. Semarang: Universitas Diponegoro; 2007.

13. Lestari T. Kumpulan teori untuk kajian pustaka penelitian kesehatan. Yogyakarta: Nuha Medika; 2014.

14. Wahyuni Y, Saad A, Suyanto. Analisis kualitatif kejadian relaps tuberkulosis paru di Puskesmas Sidomulyo Pekanbaru tahun 2011-2012. Pekanbaru: IKMKM FK Universitas Riau; 2013.

15. Yenni FP, Utami NW, Susmini. Hubungan tingkat pengetahuan keluarga pasien tentang tuberkulosis dengan kepatuhan menggunakan alat pelindung diri (APD) di ruang rawat inap Rumah Sakit Panti Waluya Malang. Nursing News [internet]. 2016 [diakses pada 31 Januari 2019]; 1(1): 12-21. Tersedia dari: https://publikasi.unitri.ac.id/index.php/fikes/article/viewFile/394/312

16. Bonita, Cahyo K, Riyanti E. Hubungan usia dan persepsi kerentanan dengan perilaku proteksi penularan TB pada anak di lima wilayah kerja Puskesmas Kota Semarang. JKM e-Journal [internet]. 2018 [diakses tanggal 31 Januari 2019]; 6(2): 151-155. Tersedia dari: http://ejournal3.undip.ac.id/index.php/jkm

17. Wulandari AA, Nurjazuli, Adi MS. Faktor risiko dan potensi penularan tuberkulosis paru di Kabupaten Kendal, Jawa Tengah. JKLI [internet]. 2015 [diakses tanggal 31 Januari 2019]; 14(1): 7-13. Tersedia dari: https://ejournal.undip.ac.id/index.php/jkli/article/view/10031

18. Dotulong JFJ, Sapulete MR, Kandou GD. Hubungan faktor risiko umur, jenis kelamin dan kepadatan hunian dengan kejadian penyakit TB paru di Desa Wori Kecamatan Wori. JKKT [internet]. 2015 [diakses tanggal 31 Januari 2019]; 3(2): 57-65. Tersedia dari: https://ejournal.unsrat.ac.id/index.php/JKKT/article/view/7773. 